\title{
Evaluation of microbial and sensory properties of flavored yogurt drink produced by Noanea mucronata and liquid smoke treatment
}

\author{
Ghazal Rahimzadeh, ${ }^{1}$ Abdullatif Tay, ${ }^{2}$ Joe Mac Regenstein, ${ }^{3}$ Asad Rokhzadi, ${ }^{4}$ Hossein Dabiri ${ }^{5}$ \\ ${ }^{1}$ Deakin University, Geelong, Australia; ${ }^{2}$ PepsiCo R\&D, Barrington, IL; ${ }^{3}$ Cornell University, Department of \\ Food Science, Ithaca, NY, USA; ${ }^{4}$ Islamic Azad University, Department of Agriculture, Sanandaj, Kurdistan, \\ Iran; ${ }^{5}$ Shahid Beheshti University of Medical Science, Department of Medical Microbiology, Faculty of \\ Medicine, Tehran, Iran
}

\begin{abstract}
Liquid smoke is more acceptable compared with traditional smoking for various practical and health reasons. This study aimed to investigate the quality attributes of yogurt drink treated with natural and liquid smoke. Yogurt drink samples were divided into four groups; natural smoked, liquid smoked at two concentrations ( 1 and $2 \mathrm{~mL} \cdot \mathrm{L}^{-1}$ ) and un-smoked control samples. Microbial and sensory attributes of yogurt drink samples were analyzed after 1,7 , 14 , and 21 days of storage at $4^{\circ} \mathrm{C}$.
\end{abstract}

Correspondence: Abdullatif Tay, PepsiCo R\&D, 617 West Main Street Barrington, IL 60010.

E-mail: Abdullatif.Tay@pepsico.com

Key words: Yogurt drink; Liquid smoke; Noaea mucronata.

Conflict of interest: The authors whose names are listed have no other affiliations with or involvement in any organization or entity with any financial interest.

Contributions: All authors discussed the results and contributed to the final manuscript.

Disclaimer: This work was not supported by PepsiCo, the views expressed in this presentation are those of the authors and do not necessarily reflect the position or policy of PepsiCo.

Ethics approval: This material is the authors' own original work, which has not been previously published elsewhere.

Availability of data and materials: Data generated and/or analyzed during the current study are available from the corresponding author on reasonable request.

Received for publication: 31 January 2020.

Revision received: 21 February 2020.

Accepted for publication: 21 February 2020

This work is licensed under a Creative Commons Attribution NonCommercial 4.0 License (CC BY-NC 4.0).

(C) Copyright: the Author(s),2020

Licensee PAGEPress, Italy

Infectious Diseases and Herbal Medicine 2020; 1:77

doi:10.4081/idhm.2020.77
The final counts of total bacteria, lactic acid bacteria, yeast and molds were significantly lower after the application of $2 \mathrm{~mL} \cdot \mathrm{L}^{-1}$ liquid smoke compared to control samples. Moreover, lactic acid bacteria of yogurt drink were not inhibited by natural smoke or 1 $\mathrm{mL} \cdot \mathrm{L}^{-1}$ liquid smoke treatments. According to the sensory evaluation and microbiological analysis, application of $1 \mathrm{~mL} \cdot \mathrm{L}^{-1}$ of liquid smoke in yogurt drink is the most appropriate and convenient alternative to the traditional smoking method.

\section{Introduction}

There is a growing demand for yogurt drinks due to their unique properties and numerous health benefits. ${ }^{1}$ Yogurt drinks are rich in potassium, calcium, protein and $\mathrm{B}$ vitamins, which help stabilize the immune system. ${ }^{2}$ In addition, yogurt drinks are beneficially ameliorated the behaviour and well-being of the consumers. ${ }^{3,4}$ Yogurt drink is known by various names in many regions such as Ayran in Turkey, Dahi and Lassi in India, Laban in Arab countries, and Doogh in Iran. ${ }^{5}$

Yogurt drink beverage is popular in Armenia, Iran, Azerbaijan, Turkey, Afghanistan, Iraq, Syria, and Balkans. ${ }^{6}$ Smoked yogurt drink is a popular kind of flavored yogurt drink that is manufactured by traditional methods in Kurdistan, Iran (Middle East, Western Asia). Its production is based on mixing prepared yogurt drink with smoke from thorny saltwort (Noaea mucronata). ${ }^{7}$

Noaea mucronata belongs to the family of Chenopodiaceae which is spread on arid and semi-arid rangelands of Middle East, North Africa and some part of Europe. The plant shrub has the sprawling branched stems terminating in sharp spines and leaves are narrowly-linear, mucronate, and slightly decurrent at the base. ${ }^{8}$ N. mucronata is commonly abounded in Mediterranean climates, with long hot dry summers and cold winters. It appears that the plant can survive a climate that's not Mediterranean at the eastern border of its native range in Iran. ${ }^{9}$ The dry matter of $N$. mucronata was found to contain $40.0 \%$ nitrogen-free extract, $23.0 \%$ dietary fiber, $13.5 \%$ total protein, $2.1 \%$ ash, and $2.3 \%$ total fat. ${ }^{10}$

Farag et al. ${ }^{11}$ showed in a study that $N$. mucronata contained 16 amino acids with the highest and lowest concentration of free amino acids being aspartic acid and histidine, respectively. They also reported that Arachidic acid is the major fatty acid of $N$. mucronata.

Also, Pharmacological effects of $N$. mucronata have been widely studied in Egypt, Saudi Arabia and Iran. ${ }^{12-14}$ N. mucronata has been used as a treatment of kidney stones in Iran. ${ }^{12}$ The plant is also widely used as a fuel for cooking and heating. ${ }^{10}$

Liquid Smoke (LS) is often preferred over traditional smoking 
because of omission of carcinogens, ease of use, greater uniformity, and repeatability of the production. ${ }^{15}$ Consequently, it can be applying as a safe alternative to food protective without mutagenic ${ }^{16}$ and carcinogenic materials. ${ }^{17}$ Liquid smoke is considered a natural flavouring and has been granted Generally Recognized as Safe (GRAS) status by the Flavor and Extract Manufacturers Association. ${ }^{18}$

Smoke applications in addition to imparting flavor, color and aroma to foods, have been used for food preservation because of their antimicrobial and antioxidant properties. ${ }^{19}$ Several studies were conducted on antibacterial activity of smoke applications in food products. ${ }^{19-24}$ Gonulalan et al. ${ }^{22}$ compared the effect of liquid smoke and traditional smoking on beef tongue. Gedela et al. ${ }^{21}$ studied the effect of liquid smoke on reduction of Listeria monocytogenes in frankfurters. Other researchers introduced LS flavouring as an alternative to traditional smoking of fish fillets; also, they found that the sensory properties of liquid smoked fish were as good as traditional smoked fillets. ${ }^{23}$

Even though many studies have reported the use of Natural Smoke (NS) and LS in food, there has been no published research on the effectiveness of smoke treatments in yogurt drinks. The objective of the present study is to ascertain effect of LS in comparison with NS on microbial and sensory attributes of yogurt drink during storage.

\section{Materials and Methods}

\section{Smoke and yogurt materials}

Hickory liquid smoke was obtained from the Reily Foods Company (New Orleans, LA, USA). According to the information published by the manufacturer the Hickory Liquid Smoke is approved by the European Parliament (EC) No 1321/2013 and $2065 / 2003$ as a smoke flavoring agent. Traditional yogurt and dried $N$. mucronata plants were purchased from a local dairy store

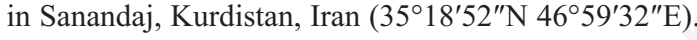

\section{Production of yogurt drink}

Yogurt drink samples were prepared by mixing the traditional yogurt $($ fat $=1.65 \%$, dry matters $=8.63 \pm 0.1 \%$ ) and distilled water at a ratio of 50:50 v/v using a mixer (Type SM, Sanyo Electric Co., Ltd, Japan) at $25^{\circ} \mathrm{C}$, then $0.01 \mathrm{w} / \mathrm{v}$ salt $(\mathrm{NaCl}$; Merck, Darmstadt, Germany) was added to this mixture.

\section{Production of smoke-flavored yogurt drink}

After preliminary sensory experiments, the appropriate concentrations of liquid smoke $\left(1\right.$ and $\left.2 \mathrm{~mL} \cdot \mathrm{L}^{-1}\right)$ were determined. Therefore, yogurt drink samples were divided into four groups; 1 : unsmoked or control; 2: traditionally smoked yogurt drink; 3: 1 $\mathrm{mL} \cdot \mathrm{L}^{-1}$ liquid smoke added; and 4: $2 \mathrm{~mL} \cdot \mathrm{L}^{-1}$ liquid smoke added

For the traditional smoking the protocol for preparing traditional smoked yogurt drink samples was provided by a local dairy store. $150 \mathrm{~g}$ of $N$. mucronata plant was burnt for $10 \mathrm{~s}$ and the flames were extinguished by covering with an aluminum foil. The remaining plant material was placed in an empty plastic container carefully. The container was allowed to fill with the smoke for 2 min. Then the plant material was removed, and 5 liters of yogurt drink sample was added to make the traditional smoked samples.

Yogurt drink samples were stored for $24 \mathrm{~h}$ at $4 \pm 1^{\circ} \mathrm{C}$ to allow equilibration. Microbial and sensory attributes of yogurt drink samples were examined after $1,7,14$, and 21 days of storage at $4^{\circ} \mathrm{C} .{ }^{24}$ The experiments were conducted for three independent batches and all microbial and sensory tests were performed in triplicates.

\section{Measurement of TA and $\mathrm{pH}$}

The $\mathrm{pH}$ and Titratable Acidity (TA) of the resulting yogurt drink samples were measured using an Accumet ${ }^{\circledR}$ Research AR15 pH meter (Fisher Scientific, Kalamazoo, Michigan, USA), and the titration was done using $\mathrm{NaOH}\left(0.1 \mathrm{~mol} \cdot \mathrm{L}^{-1}\right)$ in the presence of phenolphthalein as an indicator. ${ }^{25}$

\section{Microbiological analysis of yogurt drink samples}

First, ten milliliters of each sample was pipetted aseptically into $90 \mathrm{~mL}$ of quarter strength Ringer's solution and mixed thoroughly. Serial dilutions of samples $\left(10^{-1}\right.$ to $\left.10^{-8}\right)$ were prepared. After serial dilutions, Total Counts of Bacteria (TCB) were determined on Plate Count Agar (PCA; Merck, Darmstadt, Germany), after incubation at $30^{\circ} \mathrm{C}$ for $72 \mathrm{~h}$. Coliforms were enumerated on Violet Red Bile Agar (VRBA; Merck), after incubation at $32^{\circ} \mathrm{C}$ for $72 \mathrm{~h}$. The yeasts and molds were counted on Yeast Extract Glucose Chloramphenicol Agar (YGC; Merck) after five days of incubation at $25^{\circ} \mathrm{C} .{ }^{25}$ Total counts of Lactic Acid Bacteria (LAB) were enumerated on de Man, Rogosa and Sharpe agar (MRS; Merck), the plates were incubated in anaerobic jars under carbon dioxide-nitrogen gas atmosphere (GasPak System; BBL, Cockeysville, MD, USA) at $30{ }^{\circ} \mathrm{C}$ for $72 \mathrm{~h} .{ }^{25}$ The enumeration of Staphylococcus aureus and Escherichia coli was done using the surface spread method on Baird-Parker agar (BP; Oxoid, Basingstoke, England) and Sorbitol-MacConkey agar (SMAC; Oxoid), respectively. ${ }^{25}$ The plates for $E$. coli were incubated at $44{ }^{\circ} \mathrm{C}$ and for $S$. aureus were incubated at $37{ }^{\circ} \mathrm{C}$ for 72 h. ${ }^{25}$ Besides, biochemical confirmation tests for detecting $E$. coli and $S$. aureus were completed. ${ }^{25}$

\section{Sensory evaluation of smoked yogurt drink}

Yogurt drink samples were evaluated for odor, taste, appearance (color and existence of dark particles) and overall acceptance. Fifty panelists 25 females and 25 males, ages between 20 and 48 were recruited among students and staff. Two digits coded samples at a temperature of $4^{\circ} \mathrm{C}$ with a volume of $50 \mathrm{~mL}$ inside the clear disposable plastic cups were presented to participants after 1, 7, 14, and 21 days of storage. Participants were asked to indicate how much they liked or disliked each product on a 5-point hedonic scale (5=like extremely, 4= Like moderately, 3= Neither like nor dislike, $2=$ Dislike moderately, and $1=$ dislike extremely). Mineral water (Aquafina, Tehran, Iran) was served for rinsing between tests. An evaluation was conducted under bright lighting and at $25^{\circ} \mathrm{C}$ of room temperature. ${ }^{26}$

\section{Statistical analysis}

The obtained data were subjected to statistical analysis using a one-way ANOVA using SAS software version 9.1 (SAS Institute, Cary, NC, USA). The General Linear Model Repeated Measures was used to determine the differences between each period, and the differences between means for each parameter were determined using Duncan's multiple range test. Differences were accepted when $\mathrm{P}<0.05$.

\section{Results}

\section{TA and pH evaluation of yogurt drink samples}

According to Table 1 the effects of smoke treatments on the TA 
and $\mathrm{pH}$ of yogurt drink samples were not significantly different $(\mathrm{P}>0.05)$. However, in all treatments TA increased significantly during storage time $(\mathrm{P}<0.05)$ as the $\mathrm{pH}$ of the samples decreased significantly from $\sim 4.3$ to 4.0 at the end of storage.

\section{Microbiological evaluation of yogurt drink samples}

As shown in Table 2, smoke treatments did not have any significant effects $(\mathrm{P}>0.05)$ on LAB counts, coliform, yeast and mold and Staphylococcus spp. after one day of yogurt drink preparation. The coliform counts were not observed in any yogurt drink samples after seven days of storage. Furthermore, E. coli and $S$. aureus were not detectable in any yogurt drink samples.

LAB counts in yogurt drink samples treated with $2 \mathrm{~mL} \cdot \mathrm{L}^{-1}$ liquid smoke decreased significantly from 7.01 to $6.79 \log$ $\mathrm{CFU} \cdot \mathrm{mL}^{-1}$ during 14 days and were followed by a significant drop to the $6.28 \log \mathrm{CFU} \cdot \mathrm{mL}^{-1}$ at the end of storage time. Although

Table 1. TA and $\mathrm{pH}$ change of yogurt drink samples during storage time.

\begin{tabular}{|c|c|c|c|c|}
\hline & $1 d$ & $7 d$ & $14 d$ & $21 d$ \\
\hline \multicolumn{5}{|l|}{$T A$} \\
\hline Control & $0.603 \pm 0.013 a, D$ & $0.621 \pm 0.011 \mathrm{a}, \mathrm{C}$ & $0.648 \pm 0.013 \mathrm{a}, \mathrm{B}$ & $0.666 \pm 0.026 \mathrm{a}, \mathrm{A}$ \\
\hline N.S & $0.603 \pm 0.027 \mathrm{a}, \mathrm{D}$ & $0.621 \pm 0.025 \mathrm{a}, \mathrm{C}$ & $0.648 \pm 0.035 \mathrm{a}, \mathrm{B}$ & $0.666 \pm 0.025 \mathrm{a}, \mathrm{A}$ \\
\hline $1 \mathrm{~mL} \cdot \mathrm{L}^{-1} \mathrm{LS}$ & $0.603 \pm 0.018 \mathrm{a}, \mathrm{B}$ & $0.617 \pm 0.016 a, B$ & $0.644 \pm 0.032 \mathrm{a}, \mathrm{A}$ & $0.657 \pm 0.036 \mathrm{a}, \mathrm{A}$ \\
\hline $2 \mathrm{~mL} \cdot \mathrm{L}^{-1} \mathrm{LS}$ & $0.603 \pm 0.014 \mathrm{a}, \mathrm{B}$ & $0.612 \pm 0.013 \mathrm{a}, \mathrm{B}$ & $0.639 \pm 0.024 \mathrm{a}, \mathrm{A}$ & $0.648 \pm 0.045 \mathrm{a}, \mathrm{A}$ \\
\hline \multicolumn{5}{|l|}{ pH } \\
\hline Control & $4.312 \pm 0.013 \mathrm{a}, \mathrm{A}$ & $4.244 \pm 0.012 \mathrm{a}, \mathrm{B}$ & $4.17 \pm 0.011 \mathrm{a}, \mathrm{C}$ & $4.064 \pm 0.012 a, D$ \\
\hline N.S & $4.313 \pm 0.017 \mathrm{a}, \mathrm{A}$ & $4.241 \pm 0.056 \mathrm{a}, \mathrm{B}$ & $4.16 \pm 0.035 \mathrm{a}, \mathrm{C}$ & $4.073 \pm 0.023 a, D$ \\
\hline $1 \mathrm{~mL} \cdot \mathrm{L}^{-1} \mathrm{LS}$ & $4.324 \pm 0.012 \mathrm{a}, \mathrm{A}$ & $4.242 \pm 0.034 a, B$ & $4.17 \pm 0.033 a, C$ & $4.063 \pm 0.035 a, D$ \\
\hline $2 \mathrm{~mL} \cdot \mathrm{L}^{-1} \mathrm{LS}$ & $4.314 \pm 0.036 \mathrm{a}, \mathrm{A}$ & $4.243 \pm 0.047 \mathrm{a}, \mathrm{B}$ & $4.17 \pm 0.031 \mathrm{a}, \mathrm{C}$ & $4.064 \pm 0.037 \mathrm{a}, \mathrm{D}$ \\
\hline
\end{tabular}

Values are means \pm SE and values followed by the same capital letters in each row (Effect of storage time) or the same small letters in a group of a column (effect of different smoke treatments), are not significantly different at $\mathrm{P}<0.05$. d: days of storage. All tests were performed in triplicate for three independent experiments.

Table 2. Microbial changes $\left(\log \mathrm{CFU} \cdot \mathrm{mL}^{-1}\right)$ of yogurt drink samples during storage time.

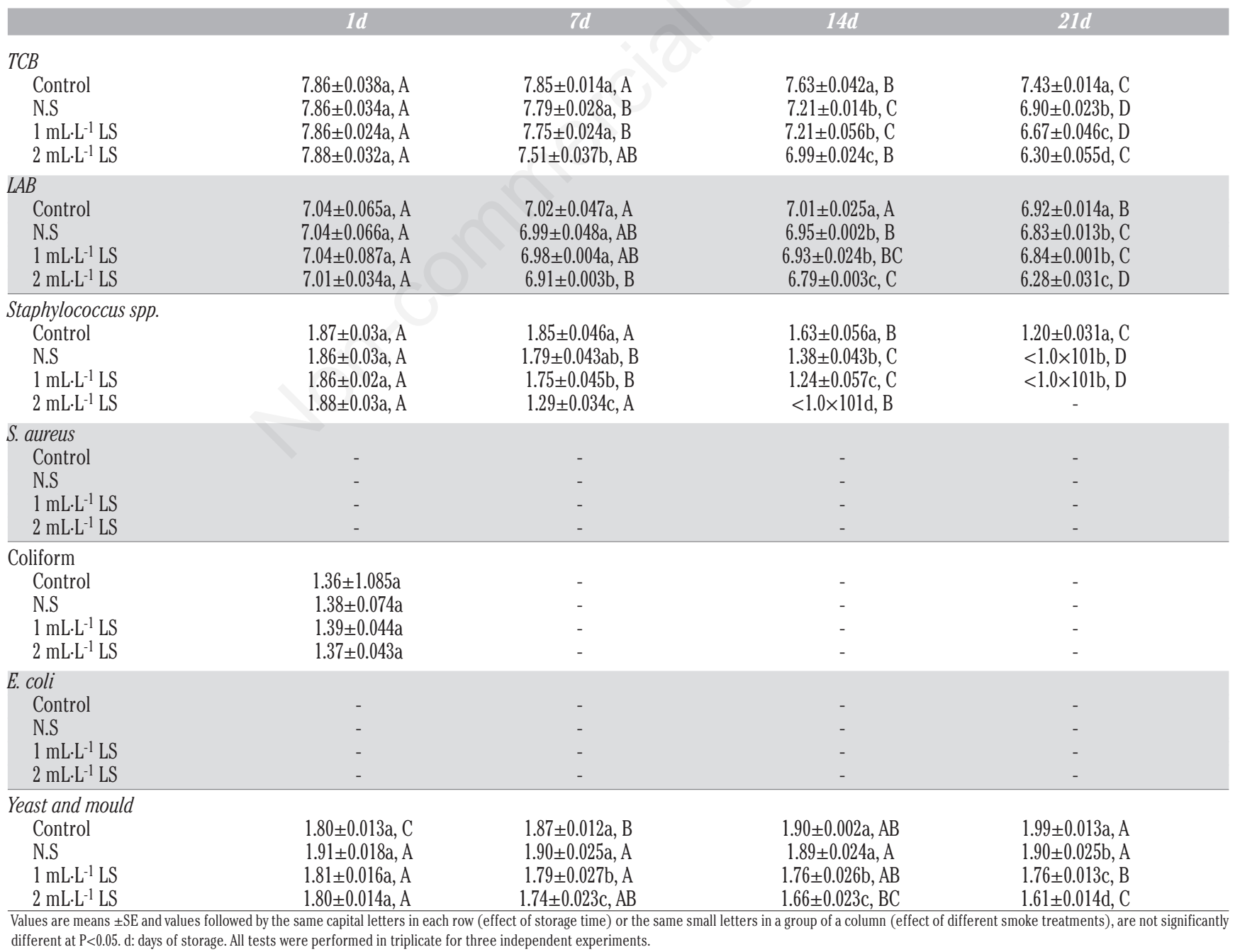


LAB counts in control samples remained stable at $7 \log \mathrm{CFU} \cdot \mathrm{mL}^{-1}$, a slight decrease was observed in LAB populations in samples treated with traditional smoke and $1 \mathrm{~mL} \cdot \mathrm{L}^{-1}$ liquid smoke during 14 days of storage $(\mathrm{P}<0.05)$. After 21 days of storage, LAB counts significantly decreased to $6.84,6.83$ and $6.92 \log \mathrm{CFU} \cdot \mathrm{mL}^{-1}$ in yogurt drink treated with $1 \mathrm{~mL} \cdot \mathrm{L}^{-1}$ liquid smoke, NS and control samples, respectively $(\mathrm{P}<0.05)$.

The populations of Staphylococcus spp. in all samples decreased significantly $(\mathrm{P}<0.05)$ during storage time in all samples. After seven days of storage, the count of Staphylococcus spp. in $2 \mathrm{~mL} \cdot \mathrm{L}^{-1}$ liquid smoked yogurt drink, $1 \mathrm{~mL} \cdot \mathrm{L}^{-1}$ liquid smoked yogurt drink and natural smoked samples were $0.56,0.1$ and $0.06 \log \mathrm{CFU} \cdot \mathrm{mL}^{-1}$ lower than the control sample. During 14 days of storage, the Staphylococcus spp. counts decreased significantly to $1.63,1.38,1.24$ and $<1 \log \mathrm{CFU} \cdot \mathrm{mL}^{-1}$ in control, natural smoked yogurt drink, $1 \mathrm{~mL} \cdot \mathrm{L}^{-1}$ and $2 \mathrm{~mL} \cdot \mathrm{L}^{-1}$ liquid smoked yogurt drink, respectively. In the following seven days, the Staphylococcus spp. counts decreased significantly to 1.20 in control, and less than $1 \log \mathrm{CFU} \cdot \mathrm{mL}^{-1}$ for all other samples respectively. Yeast and mold counts in control samples increased significantly from 1.80 to $1.99 \log \mathrm{CFU} \cdot \mathrm{mL}^{-1}$ during storage time; In contrast, in samples treated with $1 \mathrm{~mL} \cdot \mathrm{L}^{-1}$ and $2 \mathrm{~mL} \cdot \mathrm{L}^{-1}$ liquid smoke the counts of yeast and mold decreased from 1.81 to 1.76 and from 1.80 to $1.61 \log \mathrm{CFU} \cdot \mathrm{mL}^{-1}$, respectively. Yeast and mold populations in samples treated with traditional smoke remained stable during storage. The TCB of all yogurt drink samples decreased significantly $(\mathrm{P}<0.05)$ during storage. After seven days of storage, the TCB of $2 \mathrm{~mL} \cdot \mathrm{L}^{-1}$ liquid smoked yogurt drink, 1 $\mathrm{mL} \cdot \mathrm{L}^{-1}$ liquid smoked yogurt drink and natural smoked yogurt drink were $0.34,0.1$ and $0.06 \log \mathrm{CFU} \cdot \mathrm{mL}^{-1}$ lower than control samples. After 14 days, no significant differences were observed in TCB of $1 \mathrm{~mL} \cdot \mathrm{L}^{-1}$ liquid smoke and traditional smoked yogurt drink samples. On the other hand, the TCB in $2 \mathrm{~mL} \cdot \mathrm{L}^{-1}$ liquid smoke was $0.64 \log \mathrm{CFU} \cdot \mathrm{mL}^{-1}$ lower than $\mathrm{TCB}$ of control samples. At the end of 21 days, $2 \mathrm{~mL} \cdot \mathrm{L}^{-1}$ liquid smoke with 6.30 $\log \mathrm{CFU} \cdot \mathrm{mL}^{-1}$ had a lower number of TCB.

\section{Sensory evaluation of yogurt drink samples}

Table 3 presents the sensory attributes of yogurt drink samples during storage. A day after preparation, there were no significant differences regarding taste among samples $(\mathrm{P}>0.05)$. However, the samples treated with smoke had significantly higher odor scores. The natural smoked yogurt drink samples had a significantly lower score regarding appearance, and this downward trend was observed until the end of storage time. After seven days, the unsmoked control samples had significantly lower mean taste and odor score $(\mathrm{P}<0.05)$. No statistical differences were observed $(\mathrm{P}>0.05)$ between taste and odor scores of traditional smoked samples and liquid smoke samples after 7 days. After 14 days, the taste and overall acceptance of $2 \mathrm{~mL} \cdot \mathrm{L}^{-1}$ smoked yogurt drink samples and control samples had significantly higher and lower mean scores, respectively $(\mathrm{P}<0.05)$. At the end of 21 days, control samples had significantly lower taste and overall acceptance scores. However, there were no significant differences between traditional smoked samples and $1 \mathrm{~mL} \cdot \mathrm{L}^{-1}$ liquid smoked yogurt drink samples score of overall acceptance $(\mathrm{P}>0.05)$. In general, the sensory attributed of all samples were dropped significantly during 21 days of storage. However, samples treated with $2 \mathrm{~mL} \cdot \mathrm{L}^{-1}$ liquid smoke had significantly higher taste and odor scores compared with other samples.

\section{Discussion}

There has been very little research on microbiology and sensory of smoked dairy products. ${ }^{20}$ To the best of our knowledge this is the first study investigated effects of regular and liquid smoke treatments on microbial and sensory of yogurt drink samples. Thus, comparisons will be made with the results of similar studies. It is well known that metabolism of carbohydrates and formation of organic acids in yogurt contribute to the sour taste and result in $\mathrm{pH}$ decrease. ${ }^{27} \mathrm{The} \mathrm{pH}$ values for Iranian yogurt drink should be less than 4.5 .6 Similarly, various $\mathrm{pH}$ values ranging from 3.44 to 4.44 have been reported for Ayran (Turkish fermented

Table 3. Sensory attribute changes of yogurt drink samples during storage time.

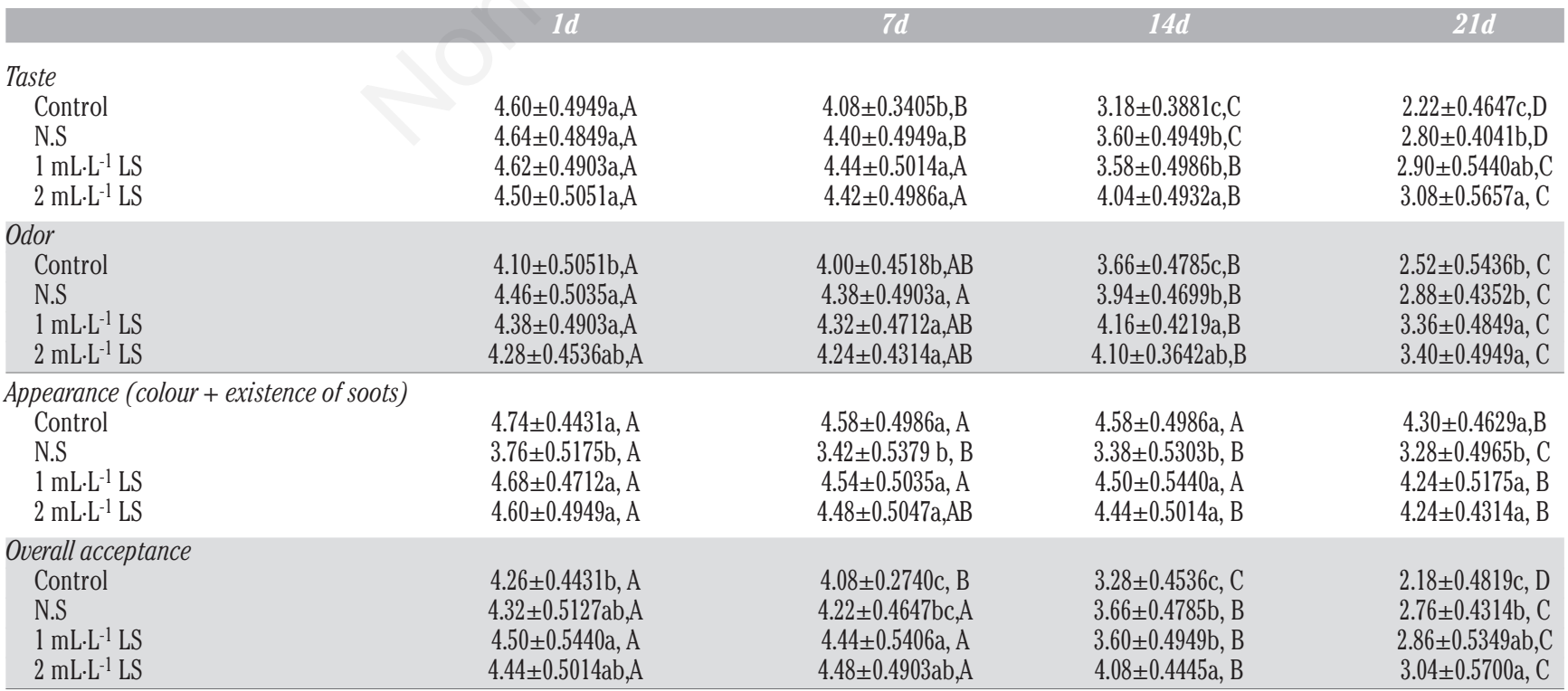

Values are means \pm SE and values followed by the same capital letters in each row (effect of storage time) or the same small letters in a group of a column (effect of different smoke treatments), are not significantly different at $\mathrm{P}<0.05$. d: days of storage. All tests were performed in triplicate for three independent experiments.1 (Dislike extremely), 2 (Dislike moderately), 3 (Neither like nor dislike), 4 (Like moderately), 5 (Like extremely). 
yogurt drink)..$^{28}$

Yeasts and molds are abundant in environments due to their ability to tolerate to low $\mathrm{pH}$ and temperature values and ability to utilize a variability of substrates. ${ }^{29}$

The results showed that the number of yeasts and molds slightly increased during storage. This might be due the acidic resistance of yeast that is reliant on the energy requiring system in cells that pump protons dynamically out of the cells and thus prohibit acidification of the cell interior; Therefore, yeasts are quite adaptive to incompatible conditions such as acidity. ${ }^{30}$ Moreover, the slight increase in yeast counts of control yogurt drink samples can be attributed to the nutritional profile and low $\mathrm{pH}$ of yogurt drinks, which are favorable for the growth of spoilage. ${ }^{31}$ According to the Iranian regulations for pasteurized yogurt drink the counts of coliform, yeast and molds should be less than 10 and $100 \mathrm{CFU} \cdot \mathrm{mL}^{-1}$, respectively, and the yogurt drink should be free of E. coli and S. aureus. ${ }^{6}$ Mehraban et al. ${ }^{32}$ reported up to $5.7 \times 10^{2} \mathrm{CFU} \cdot \mathrm{mL}^{-1}$ of coliforms and $3 \times 10^{7} \mathrm{CFU} \cdot \mathrm{mL}^{-1}$ for $\mathrm{LAB}$ in yogurt drink samples, these counts are similar to our findings of LAB and coliform counts; however, they reported higher yeast counts $\left(1.2 \times 10^{5} \mathrm{CFU} \cdot \mathrm{mL}^{-1}\right)$ in comparison to our results. Furthermore, the $\mathrm{LAB}$ counts at the end of storage was in agreement with reported results by Birollo et al. ${ }^{33}$ which indicated counts up to $10^{7} \mathrm{CFU} \cdot \mathrm{g}^{-1}$ in yogurt at the end of 30-day storage time. For yogurt products the minimum acceptable levels of LAB counts are established as $10^{6} \mathrm{CFU} \cdot \mathrm{g}^{-1}$ in Switzerland and Italy, $10^{7}$ CFU. $\mathrm{g}^{-1}$ in Japan and $10^{8} \mathrm{CFU} \cdot \mathrm{g}^{-1}$ in Portugal. ${ }^{34}$ The LAB counts for $1 \mathrm{~mL} \cdot \mathrm{L}^{-1} \mathrm{LS}$ treatment was around $10^{7} \mathrm{CFU} \cdot \mathrm{mL}^{-1}$ at the end of 21 days of storage and was consistently higher compared to LAB counts for the $2 \mathrm{~mL} \cdot \mathrm{L}-1 \mathrm{LS}$ samples.

The presence of Staphylococcus spp. may indicate the poor sanitary and handling during the production and distribution of locally produced yogurt. ${ }^{35} \mathrm{As} \mathrm{pH}$ values for yogurt drink samples decreased, the conditions became unfavorable for Staphylococcus spp. Thus, toward the end of the storage, Staphylococcus spp. were undetectable in yogurt. ${ }^{35}$

The decrease in TCB, LAB and Staphylococcus spp. counts over time for control samples may be related to nutrition limitations, as well as some organisms entering the death phase. ${ }^{36}$

The reductions in LAB counts for smoked yogurt drink samples are in agreement with the other study which showed that the inhibitory effect of liquid smoke on LAB increased with an increase in smoke concentration. ${ }^{37}$ It has been proposed that phenols (Cresol, Guaiacol, Syringol, and Pyrocatechol) are the main components in liquid smoke responsible for the antimicrobial activity. ${ }^{38}$ In agreement with results of our study, researchers indicated that the Staphylococcus were considerably more sensitive to liquid smoke compared to $\mathrm{LAB}^{39}$ The low $\mathrm{pH}$ of yogurt drink samples is the main reason of Staphylococcus inhibition. Also, the minimal values of $\mathrm{pH}$ for growth are influenced by other environmental factors. ${ }^{40}$ The inhibition of $S$. aureus has been shown by applying $1 \mathrm{~mL} \cdot \mathrm{L}^{-1}$ acetic acid. ${ }^{40}$ Therefore, the inhibition of Staphylococcus spp. using $2 \mathrm{~mL} \cdot \mathrm{L}^{-1}$ liquid smoke may be attributed to the amount of acetic acid contained in the liquid smoke. ${ }^{41}$ The inhibition may also be due to the production of anti-staphylococcal compounds by the LAB. ${ }^{42}$ Acidic stress and $\mathrm{pH}$ can damage cell membrane structures and reduce the activity of enzymes. Therefore, it seems that acidic stress and low $\mathrm{pH}$ may be the main reasons for the inhibition of staphylococci. ${ }^{43}$ Coliforms have been reported to grow over a $\mathrm{pH}$ range of 4.4-9.0. ${ }^{36}$ The inhibition of coliform growth probably is due to the low $\mathrm{pH}$ of yogurt drink samples. Similar results were reported that $E$. coli $\mathrm{O} 157: \mathrm{H} 7$ could not survive in the yogurt. ${ }^{44}$ In contrast, other researcher found that coliforms can survive at $\mathrm{pH}$ of 3.67 in unheated yogurt drink samples. ${ }^{26}$ Furthermore, no significant change in coliform counts was observed on the first day of smoke treatments suggesting that there is a lag time for smoke to be active on microorganisms in complex food systems. ${ }^{38}$ Results of sensory analysis of current study are in agreement with earlier research in which they showed that the taste of yogurt drink samples changed during storage, as they showed the microbial metabolites, lipase, and ambient temperature are the most important factors for off- flavor of yogurt drink samples during storage time. ${ }^{45}$ Also, a significant drop in sensory characteristics of fermented milk during storage time has been reported. ${ }^{46}$

The amount of acetaldehyde in yogurt drink samples probably decreased due to the degradation of acetaldehyde at lower $\mathrm{pHs}$ and enhanced oxidization during storage. ${ }^{47}$ Furthermore, it can be suggested that $2 \mathrm{~mL} \cdot \mathrm{L}^{-1}$ liquid smoke can dominate and mask the off- flavor of yogurt drink at the end of storage. It is reported that phenolic compounds contribute to the smoke flavor of liquid smokes besides their antibacterial and antioxidant properties. ${ }^{38}$

The odor of smoked yogurt drink is due to volatile compounds present in the smoke condensate. Previous studies revealed that the most fraction of odor-active compounds in liquid smoke were alkyl and carbonyl derivatives of syringol and guaiacol. ${ }^{48}$ In agreement with our results for liquid smoke samples, it showed that the sensory quality of liquid smoke treated samples were as good as that of traditional smoking. ${ }^{49}$

In conclusions, both sensory and microbial evaluations showed that excessive amount of liquid smoke is not suitable in yogurt drink products, therefore, the lower amount of liquid smoke can be the most advisable alternative to natural smoking to produce a safe and similar tasting yogurt drink product.

\section{References}

1. Ebringer L, Ferenčík M, Krajčovič J. Beneficial health effects of milk and fermented dairy products. Folia Microbiol 2008;53:378-94.

2. O'Connell JE, Fox PF. Significance and applications of phenolic compounds in the production and quality of milk and dairy products: a review. Int Dairy J 200;11:103-20.

3. Ejtahed HS, Mohtadi-Nia J, Homayouni-Rad A, et al. Effect of probiotic yogurt containing Lactobacillus acidophilus and Bifidobacterium lactis on lipid profile in individuals with type 2 diabetes mellitus. J Dairy Sci 2011;94:3288-94.

4. Kalantari N, Doaei S, Gordali M, et al. The association between Dairy Intake, Simple Sugars and Body-Mass Index with Expression and Extent of Anger in Female-Students. Iranian J Psychiatry 2016;11:43.

5. Kiani H, Mousavi ME, Razavi H, Morris ER. Effect of gellan, alone and in combination with high-methoxy pectin, on the structure and stability of doogh, a yogurt-based Iranian drink. Food Hydrocolloids 2010;24:744-54.

6. ISIRI NO 2453. 2008. Doogh, Specifications and test method. Iran: Institute of Standards and Industrial Research of Iran. http://isiri.gov.ir/portal/home/?148514/\%D9\%81\%D9\%87\%D $8 \%$ B 1 \% D $8 \%$ B 3 \% D $8 \%$ A A - \% D $8 \%$ A $7 \%$ D $8 \%$ B $3 \%$ D8\%AA\%D8\%A7\%D9\%86\%D8\%AF\%D8\%A7\%D8\%B1\% D $8 \%$ A F \% D 9\% $87 \%$ D $8 \%$ A 7 \% D B \% 8 C - \% D 9\% $85 \%$ D $9 \% 84 \%$ D B \% 8 C - \% D A \% A $9 \%$ D $8 \%$ A $7 \%$ D $8 \%$ B1\%D8\%A $8 \%$ D8\%B1. In Farsi.

7. Rahimzadeh G, Rokhzadi A, Bahramian S. Antibacterial Activity Of Liquid Smoke And Pistacia Atlantica Subsp. 
Kurdica On Lactobacillus Bulgaricus. J Food Microbiol 2014;1.

8. Gintzburger G. Rangelands of the arid and semi-arid zones in Uzbekistan. Editions Quae; 2003.

9. Morsy AA, Youssef AM, Mosallam HA, Hashem AM. Assessment of selected species along Al-Alamein-Alexandria international desert road, Egypt. J Appl Sci Res 2008;4:1276-84.

10. Musselman LJ. Major Native Plant Species in Khanasser Area, Syria (Al-Hass and Shbeith Mountains). Economic Botany 2007;61:106.

11. Farag AM, Morsi SM, Emam SS, Emarah NM. Phytochemical studies on Noaea mucronata Forssk. Bulletin of Faculty of Agriculture, University of Cairo. 2000;51:175-89.

12. Ghasemi PA, Momeni M, Bahmani M. Ethnobotanical study of medicinal plants used by Kurd tribe in Dehloran and Abdanan districts, Ilam province, Iran. Afr J T Complement Altern Med 2013;10:368-85.

13. El Eraky WI. Pharmacological effects of noaea mucronata. Egyptian J Med Lab Sci 2001;10:13-24.

14. Mossa JS, Al-Yahya MA, Al-Meshal IA. Medicinal Plants of Saudi Arabia. Riyadh: King Saud University Press, 1987.

15. Suñen E, Fernandez-Galian B, Aristimuño C. Antibacterial activity of smoke wood condensates against Aeromonas hydrophila, Yersinia enterocolitica and Listeria monocytogenes at low temperature. Food Microbiol 2001;18: 387-93.

16. Kažimírová A, Jablonická A. Evaluation of potential mutagenic effect of the liquid smoke preparation UTP in vivo: cytogenetic analysis of mouse bone marrow. Mutat Res Lett 1994;323:8992.

17. Budijanto S, Hasbullah R, Prabawati S, et al. Identification and safety test on liquid smoke made from coconut shell for food product. Indones J Agric Postharvest Res 2008;5:32-40.

18. Boylston T, Chen F, Coggins P, et al. Handbook of meat, poultry and seafood quality. John Wiley \& Sons; 2012.

19. Milly PJ, Toledo RT, Ramakrishnan S. Determination of minimum inhibitory concentrations of liquid smoke fractions. J Food Sci 2005;70:M12-7.

20. Majcher MA, Goderska K, Pikul J, Jeleń HH. Changes in volatile, sensory and microbial profiles during preparation of smoked ewe cheese. J Sci Food Agric 2011;91:1416-23.

21. Gedela S, Escoubas JR, Muriana PM. Effect of inhibitory liquid smoke fractions on Listeria monocytogenes during long-term storage of frankfurters. J Food Protection 2007;70:386-91.

22. Gonulalan Z, Kose A, Yetim H. Effects of liquid smoke on quality characteristics of Turkish standard smoked beef tongue. Meat Sci 2004;66:165-70.

23. Hattula T, Elfving K, Mroueh UM, Luoma T. Use of liquid smoke flavouring as an alternative to traditional flue gas smoking of rainbow trout fillets (Oncorhynchus mykiss). LWTFood Sci Technol 2001;34:521-5.

24. Deibler KD, Delwiche J. Handbook of flavor characterization. Taylor \& Francis; 2003.

25. Wehr HM, Frank JF, American Public Health Association, editors. Standard methods for the examination of dairy products. Washington, DC: American Public Health Association; 2004.

26. Lawless HT, Heymann H. Sensory evaluation of food: principles and practices. New York: Springer Science \& Business Media; 2013.

27. Zourari AA, Accolas JP, Desmazeaud MJ. Metabolism and biochemical characteristics of yogurt bacteria. A review. Le lait 1992;72:1-34.

28. Gülmez M, Güven A, Sezer Ç, Duman B. Evaluation of microbiological and chemical quality of ayran samples marketed in Kars and Ankara cities in Turkey. Kafkas Üniversitesi
Veteriner Fakültesi Dergisi 2003;9:49-52.

29. in't Veld JH. Microbial and biochemical spoilage of foods: an overview. Int J Food Microbiol 1996;33:1-8.

30. Deak T. Handbook of food spoilage yeasts. CRC press; 2007.

31. Rohm H, Eliskases-Lechner F, Bräuer M. Diversity of yeasts in selected dairy products. J Applied Bacteriol 1992;72:370-6.

32. Mehraban SM, Sarabi JM, Karajian R, et al. Evaluation of microbiological contamination sources of spoilage of Iranian yoghurt drink during production processes. J Food Res 2011;1:45-55 (in Farsi).

33. Birollo GA, Reinheimer JA, Vinderola CG. Viability of lactic acid microflora in different types of yoghurt. Food Res Int 2000;33:799-805.

34. Law BA (ed.). Microbiology and biochemistry of cheese and fermented milk. New York: Springer Science \& Business Media;1997.

35. Pazakova J, Turek P, Laciakova A. The survival of Staphylococcus aureus during the fermentation and storage of yoghurt. J Appl Microbiol 1997;82:659-62.

36. Jay JM, Loessner MJ, Golden DA. Foodborne listeriosis. Modern Food Microbiol 2005:591-617.

37. Donnelly LS, Ziegler GR, Acton JC. Effect of liquid smoke on the growth of lactic acid starter cultures used to manufacture fermented sausage. J Food Sci 1982;47:2074-5.

38. Varlet V, Serot T, Prost C. Smoke flavoring technology in seafood. Handbook of seafood and seafood products analysis. 2010:233-54.

39. Handford PM, Gibbs BM. Antibacterial effects of smoke constituents on bacteria isolated from bacon. Microbial Inhibitors in Food 1964:333-46.

40. Normanno G, La Salandra G, Dambrosio A, et al. Occurrence, characterization and antimicrobial resistance of enterotoxigenic Staphylococcus aureus isolated from meat and dairy products. Int J Food Microbiol 2007;115: 290-296.

41. Oramahi HA, Diba F. Maximizing the production of liquid smoke from bark of Durio by studying its potential compounds. Procedia Environ Sci 2013;17:60-9.

42. Le Marc Y, Valík L, Medved'ová A. Modelling the effect of the starter culture on the growth of Staphylococcus aureus in milk. Int J Food Microbiol 2009;129:306-11.

43. Baker-Austin C, Dopson M. Life in acid: $\mathrm{pH}$ homeostasis in acidophiles. Trends Microbiol 2007;15:165-71.

44. Dineen SS, Takeuchi K, Soudah JE, Boor KJ. Persistence of Escherichia coli O157: H7 in dairy fermentation systems. J Food Protection 1998;61:1602-8.

45. Mirchooli BA, Sedaghat, N. Effect of packaging and temperature on the shelf life of free gas Doogh. Innovation Food Sci Technol 2011 2:1-8 (in Farsi).

46. Tonguc IE, Kinik O, Kesenkas H, Acu M. Physicochemical, microbiological and sensory characteristics of using different probiotic fermented milk. Pakistan J Nutr 2013;12:549-54.

47. Varga F. The origins, production and control of acetaldehyde in yoghurt. Doctoral dissertation, University of Reading; 1998.

48. Guillen MD, Manzanos MJ, Zabala L. Study of a commercial liquid smoke flavoring by means of gas chromatography/mass spectrometry and Fourier transform infrared spectroscopy. J Agric Food Chem 1995;43:463-8.

49. Morais CD, Machado TM, Tavares M, et al. Defumaçäo líquida da truta arco-íris (Oncorhynchus mykiss): efeitos do processamento e da estocagem nas propriedades físicas, químicas e sensoriais. Rev Inst Adolfo Lutz 1996:43-8. 